$\varnothing$ CHOICE

\title{
Exercise-associated collapse: an evidence-based review and primer for clinicians
}

\author{
Chad A Asplund, ${ }^{1}$ Francis G O'Connor, ${ }^{2}$ Timothy D Noakes ${ }^{3,4}$
}

'Department of Family Medicine, Eisenhower Army Medical Center, Fort Gordon Georgia, USA

${ }^{2}$ Military and Emergency Medicine, Uniformed Services University of the Health Sciences, Bethesda, Maryland, USA

${ }^{3}$ MRC/UCT Research Unit for Exercise Science and Sports Medicine, University of Cape Town, Cape Town, South Africa

${ }^{4}$ Department of Human Biology, Sports Science Institute of South Africa, Cape Town, South Africa

\section{Correspondence to}

Chad A Asplund, Department of Family Medicine,

Eisenhower Army Medical Center, Fort Gordon, GA 30905, USA;

chad.asplund@gmail.com

Accepted 25 August 2011 Published Online First 26 September 2011

\begin{abstract}
Exercise-associated collapse (EAC) commonly occurs after the completion of endurance running events. EAC is a collapse in conscious athletes who are unable to stand or walk unaided as a result of light headedness, faintness and dizziness or syncope causing a collapse that occurs after completion of an exertional event. Although EAC is perhaps the most common aetiology confronted by the medical provider attending to collapsed athletes in a finish-line tent, providers must first maintain vigilance for other potential life-threatening aetiologies that cause collapse, such as cardiac arrest, exertional heat stroke or exercise-associated hyponatraemia. Previously, it has been believed that dehydration and hyperthermia were primary causes of EAC. On review of the evidence, EAC is now believed to be principally the result of transient postural hypotension caused by lower extremity pooling of blood once the athlete stops running and the resultant impairment of cardiac baroreflexes. Once life-threatening aetiologies are ruled out, treatment of EAC is symptomatic and involves oral hydration and a Trendelenburg position total body cooling, intravenous hydration or advanced therapies is generally not needed.
\end{abstract}

\section{INTRODUCTION}

Endurance sports are increasingly popular with over 500000 participants in marathon running events in 2010. ${ }^{1}$ After marathon running events, one study demonstrated that an estimated 25 of every 1000 finishers seek medical attention; however, this number can be highly dependent on environmental conditions. ${ }^{23}$ Of those runners seeking medical attention, exercise-associated collapse (EAC) is the most common condition seen in the medical tent, comprising $59-85 \%$ of all visits after marathons and ultramarathons. $^{2}{ }^{4}$ The mechanism of EAC is multifactorial and has previously been attributed to hyperthermia or dehydration. ${ }^{5-7}$ Currently, however, EAC is believed to be principally the result of transient postural hypotension caused by lower extremity pooling of blood once the athlete stops running and the resultant impairment of cardiac baroreflexes. ${ }^{89}$ The purpose of this article is to review the available evidence to better elucidate the mechanisms of EAC to ensure the best treatment modalities and to provide clinicians with an evidence-based algorithm to guide race day management.

\section{METHODS}

Medline, limited to human subjects and English language, was searched using the following terms: 'exercise-associated collapse', 'exercise-associated postural hypotension', 'postexercise collapse' and 'exercise and orthostatic intolerance', which resulted in 86 articles, of which 26 were review articles. The abstracts of the articles were reviewed, and the references from the review articles were also reviewed, and a total of 34 studies deemed appropriate. Evidence was graded using the Oxford Centre for Evidence-Based Medicine 2011 Levels of Evidence. ${ }^{10}$

\section{DEFINITIONS}

\section{Exercise-associated collapse}

Collapse in conscious athletes who are unable to stand or walk unaided as a result of light headedness, faintness and dizziness or syncope causing a collapse that occurs after completion of an exertional event or stopping exercise. ${ }^{11}$

\section{Exercise-associated postural hypotension}

Postexercise symptoms caused by a decline in systolic blood pressure by at least $20 \mathrm{~mm} \mathrm{Hg}$ below supine values on assuming the upright posture. ${ }^{4}$

\section{Orthostatic intolerance}

Symptoms caused by orthostatic hypotension, which is a sustained reduction of systolic blood pressure of at least $20 \mathrm{~mm} \mathrm{Hg}$ or diastolic blood pressure of $10 \mathrm{~mm} \mathrm{Hg}$ within 3 min of standing. ${ }^{12}$

Although EAC, exercise-associated postural hypotension (EAPH) and orthostatic intolerance (OI) all describe potential causes of syncope or presyncope, EAC and EAPH are specific to exercise. EAPH is differentiated from EAC in that blood pressures have been measured and found to be different in a supine and standing position. However, both EAPH and EAC describe collapse in athletes after exertion.

\section{HEAT STROKE AND HYPONATRAEMIA}

Exertional heat stroke (EHS) is characterised by central nervous system dysfunction, which may manifest as collapse or syncope, associated with an increased core body temperature $\left(>40^{\circ} \mathrm{C}\right)$, which is induced by exercise. ${ }^{13} 14$ Exercise-associated hyponatraemia $(\mathrm{EAH})$ is a potentially life-threatening condition characterised by a decrease in serum sodium $(<135 \mathrm{mmol} / \mathrm{L})$ and mental status changes. Athletes with EAH may have true syncope, confusion or disorientation but will have alteration in serum sodium. ${ }^{15}$

Although EHS and EAH can be causes of collapse in endurance sporting activities, they are associated with abnormal vital signs and symptoms and should be considered and ruled out before considering a diagnosis of EAC. The focus of this review is EAC, its mechanism and treatment; therefore, EHS and EAH will not be discussed further in this review. 


\section{MECHANISM OF EAC}

Endurance training is associated with an increased cardiac output and volume load on the left and right ventricles, causing the endurance-trained heart to a dilatation of the left ventricle combined with a mild-to-moderate increase in left ventricular wall thickness. This training-induced increase in cardiac output allows trained athletes to have a lower resting heart rate compared with the non-trained athletes. Furthermore, during exercise, the active muscles of the lower extremities require increased blood flow, and therefore, peripheral vascular resistance decreases to accommodate this need. To generate this large cardiac output, and to counter the resting decrease in heart rate secondary to training effect, athletes must increase their stroke volume and vascular resistance. Working skeletal muscle functions as a 'second heart', ensuring cardiac return to the heart from the dilated lower extremity vasculature. On cessation of activity, the second heart effect no longer assists venous return, and large volumes of blood may pool in the lower extremities and contribute to EAC. Therefore, the very adaptations that contribute to successful completion of endurance activities are also a large factor in the increased OI found in endurance athletes.

Evidence supports this increased susceptibility to OI in exercise-trained athletes. Studies support the concept of increase in calf and lower extremity compliance and increased diastolic chamber compliance and distensibility as contributors to OI in athletes. ${ }^{16-18}$ Endurance athletes have larger increases in left ventricular end-diastolic volume compared with non-athletes, which allow them to generate the necessary larger stroke volume. ${ }^{19}$ Trained athletes also demonstrated a decreased ventricular untwisting rate compared with non-trained athletes, demonstrating the trained heart's ability to adapt to maintain cardiac output. ${ }^{20}$ Training-related expansion of vascular volume is associated with decreased heart rate response to baroreceptor stimulation. ${ }^{21}$ In addition, this exercise-induced change in cardiac filling volume and output may lead to a resetting of the cardiopulmonary baroreflex. ${ }^{22}$ Because of this reset baroreflex, trained individuals may depend more on maintenance of venous return to maintain upright body position after exercise. ${ }^{23}$ Finally, a critical review supports the exercise-induced increase

Table 1 Mechanism

\begin{tabular}{|c|c|c|c|c|c|c|}
\hline Ref & Author/journal & Year & Study type & Patients & Outcome & LOE \\
\hline 16 & $\begin{array}{l}\text { Morikawa et al } \\
\text { Med Sci Sports Exerc }\end{array}$ & 2001 & Controlled trial & $\begin{array}{l}26 \text { female runners, } 23 \text { age- } \\
\text { matched controls }\end{array}$ & $\begin{array}{l}\text { Exercise-trained females have a high level of } \\
\text { orthostatic intolerance during LBNP. Increase in leg } \\
\text { compliance may play an important role }\end{array}$ & 2 \\
\hline 17 & $\begin{array}{l}\text { Levine et al } \\
\text { Circulation }\end{array}$ & 1991 & Controlled trial & 7 athletes and 6 controls & $\begin{array}{l}\text { Endurance athletes have greater diastolic chamber } \\
\text { compliance and distensibility than non-athletes }\end{array}$ & 2 \\
\hline 18 & $\begin{array}{l}\text { Levine et al } \\
\text { J Appl Physiol }\end{array}$ & 1991 & Controlled trial & $\begin{array}{l}8 \text { high fit, } 8 \text { mid fit and } 8 \\
\text { low-fit athletes }\end{array}$ & $\begin{array}{l}\text { Calf compliance and carotid baroreflex response } \\
\text { contributed to individualised response to LBNP }\end{array}$ & 2 \\
\hline 19 & $\begin{array}{l}\text { Esch et al } \\
\text { Am J Physiol Heart Circ Physiol }\end{array}$ & 2007 & Controlled trial & 8 athletes and 8 controls & $\begin{array}{l}\text { Endurance athletes had larger increases in left } \\
\text { ventricular end-diastolic volume compared with non- } \\
\text { athletes despite similar right ventricular cavity area }\end{array}$ & 2 \\
\hline 20 & $\begin{array}{l}\text { Esch et al } \\
\text { J Appl Physiol }\end{array}$ & 2010 & Controlled trial & 8 athletes and 8 controls & $\begin{array}{l}\text { Endurance athletes demonstrated a decreased left } \\
\text { ventricular untwisting rate compared with non-athletes }\end{array}$ & 2 \\
\hline 21 & $\begin{array}{l}\text { Convertino } \\
\text { Med Sci Sports Exerc }\end{array}$ & 2003 & Controlled trial & 8 men & $\begin{array}{l}\text { Expansion of vascular volume after exercise is } \\
\text { associated with reduced heart rate response to } \\
\text { baroreceptor stimulation }\end{array}$ & 2 \\
\hline 22 & $\begin{array}{l}\text { Ogoh et al } \\
\text { J Appl Physiol }\end{array}$ & 2006 & Clinical trial & 8 men & $\begin{array}{l}\text { Cardiopulmonary baroreflex may be reset during } \\
\text { exercise to a new operating point associated with } \\
\text { exercise-induced change in cardiac filling volume }\end{array}$ & 2 \\
\hline 23 & $\begin{array}{l}\text { Ogoh et al } \\
\text { J Physiol }\end{array}$ & 2003 & Clinical trial & 14 men & $\begin{array}{l}\text { Highly fit individuals depend more on maintenance of } \\
\text { venous return to maintain upright body position }\end{array}$ & 2 \\
\hline 24 & $\begin{array}{l}\text { Convertino } \\
\text { Med Sci Sports Exerc }\end{array}$ & 1993 & Critical review & NA & $\begin{array}{l}\text { Increased stroke volume is the main mechanism of } \\
\text { compensation in aerobic trained individuals }\end{array}$ & 3 \\
\hline
\end{tabular}

LBNP, lower body negative pressure; LOE, level of evidence.

Table 2 Dehydration/heat

\begin{tabular}{|c|c|c|c|c|c|c|}
\hline Ref & Author/journal & Year & Study type & Patients & Outcome & LOE \\
\hline 23 & $\begin{array}{l}\text { Ogoh et al } \\
\text { JPhysiol }\end{array}$ & 2003 & Clinical trial & 14 men & $\begin{array}{l}\text { Baroreflex response to progressive depletion of central } \\
\text { blood volume is attenuated in endurance training }\end{array}$ & 2 \\
\hline 26 & $\begin{array}{l}\text { Crandall } \\
\text { Am J Physiol Heart Circ Physiol }\end{array}$ & 2000 & Controlled trial & 12 subjects & $\begin{array}{l}\text { Reduced baroreflex response coupled with a reduction in } \\
\text { ability to increase heart rate may contribute to increased } \\
\text { susceptibility to } 0 \text { l }\end{array}$ & 2 \\
\hline 27 & $\begin{array}{l}\text { Cheuvront et al } \\
\text { J Appl Physiol }\end{array}$ & 2010 & Critical review & NA & $\begin{array}{l}\text { Dehydration augments hyperthermia and reduced plasma } \\
\text { volume, which accentuates cardiovascular strain }\end{array}$ & 3 \\
\hline 28 & $\begin{array}{l}\text { Wilson et al } \\
\text { Am J Physiol Regul Integr Com } \\
\text { Physiol }\end{array}$ & 2006 & Controlled trial & 15 men & $\begin{array}{l}\text { Heat stress decreases cerebral blood velocity and } \\
\text { increases cerebral vascular resistance }\end{array}$ & 2 \\
\hline 29 & $\begin{array}{l}\text { Charkoudian et al } \\
\text { J Physiol }\end{array}$ & 2003 & Controlled trial & 13 healthy subjects & $\begin{array}{l}\text { Exercise-induced dehydration leads to changes in } \\
\text { baroreflex control of blood pressure }\end{array}$ & 2 \\
\hline 30 & $\begin{array}{l}\text { Holtzhausen et al } \\
\text { Med Sci Sports Exerc }\end{array}$ & 1995 & Clinical trial & 31 runners & $\begin{array}{l}\text { All runners were volume depleted (average of } 4.6 \% \\
\text { deficit), } 68 \% \text { developed asymptomatic EAPH, dehydration } \\
\text { did not compromise cardiovascular status }\end{array}$ & 2 \\
\hline
\end{tabular}


Table 3 Baroreflex modulation

\begin{tabular}{|c|c|c|c|c|c|c|}
\hline Ref & Author/journal & Year & Study type & Patients & Outcome & LOE \\
\hline 31 & $\begin{array}{l}\text { Murrell et al } \\
\text { J Appl Physiol }\end{array}$ & 2007 & Clinical trial & 7 athletes & $\begin{array}{l}\text { After exercise, hypotension and postural reduction in } \\
\text { autonomic function or baroreflex control place the brain } \\
\text { at risk for hypoperfusion }\end{array}$ & 2 \\
\hline 33 & $\begin{array}{l}\text { Gratze et al } \\
\text { Eur Heart J }\end{array}$ & 2008 & Clinical trial & 51 men & $\begin{array}{l}\text { Postexercise } 0 \text { is associated with a high basal } \\
\text { sympathetic modulation of vasomotor tone in } \\
\text { combination with diminished orthostatic response to } \\
\text { resistance vessels }\end{array}$ & 2 \\
\hline 34 & $\begin{array}{l}\text { Privett et al } \\
\text { Br J Sports Med }\end{array}$ & 2010 & Clinical trial & $\begin{array}{l}10 \text { experienced male } \\
\text { runners }\end{array}$ & $\begin{array}{l}\text { After prolonged exercise, SBP decreases as a result of } \\
\text { inadequately compensated decrease in SV and resultant } \\
\text { CO from standing }\end{array}$ & 2 \\
\hline 35 & $\begin{array}{l}\text { Fu et al } \\
\text { Am J Phsiol Heart Circ Physiol }\end{array}$ & 2004 & Controlled trial & 10 women and 13 men & $\begin{array}{l}\text { Lower orthostatic intolerance in women is associated } \\
\text { with decreased cardiac filling rather than decreased } \\
\text { vascular resistance compared with men }\end{array}$ & 2 \\
\hline
\end{tabular}

LOE, level of evidence; $0 \mathrm{O}$, orthostatic intolerance; SBP, systolic blood pressure.

Table 4 Other

\begin{tabular}{|c|c|c|c|c|c|c|}
\hline Ref & Author/journal & Year & Study type & Patients & Outcome & LOE \\
\hline 36 & $\begin{array}{l}\text { Adler et al } \\
\text { Diabetes }\end{array}$ & 2009 & Clinical trial & 20 men & $\begin{array}{l}\text { Baroreflex sensitivity and response to hypotensive } \\
\text { stress are attenuated by antecedent hypoglycaemia }\end{array}$ & 2 \\
\hline 37 & $\begin{array}{l}\text { Howden et al } \\
\text { Exp Physiol }\end{array}$ & 2004 & Case-control & 9 subjects & $\begin{array}{l}\text { Increased arterial } \mathrm{CO}_{2} \text { may be associated with } \\
\text { increased cerebral blood flow }\end{array}$ & 3 \\
\hline 38 & $\begin{array}{l}\text { Lucas et al } \\
\text { J Appl Physiol }\end{array}$ & 2008 & Crossover & 9 men & $\begin{array}{l}\text { During prolonged exercise, postural-induced } \\
\text { hypotension and hyocapnia exacerbate cerebral } \\
\text { hypoperfusion }\end{array}$ & 3 \\
\hline 39 & $\begin{array}{l}\text { Middleton et al } \\
\text { Eur J Clin Pharmacol }\end{array}$ & 1987 & Case-control & $\begin{array}{l}7 \text { women and } 7 \\
\text { controls }\end{array}$ & $\begin{array}{l}\text { Significant impairment of cardiovascular reflex } \\
\text { responses while taking antidepressant medications }\end{array}$ & 3 \\
\hline 40 & $\begin{array}{l}\text { Lockwood et al } \\
\text { J Physiol }\end{array}$ & 2005 & Randomized-controlled trial & $\begin{array}{l}14 \text { healthy men and } \\
\text { women }\end{array}$ & $\begin{array}{l}\mathrm{H} 1 \text { receptor antagonist reduces vasodilatation after } \\
\text { exercise and bluntspost exercise hypotension }\end{array}$ & 1 \\
\hline 41 & $\begin{array}{l}\text { McCord et al } \\
\text { J Appl Physiol }\end{array}$ & 2006 & Randomised-controlled trial & $\begin{array}{l}10 \text { healthy men and } \\
\text { women }\end{array}$ & $\begin{array}{l}\mathrm{H} 2 \text { receptor antagonist reduces vasodilatation after } \\
\text { exercise and blunts postexercise hypotension }\end{array}$ & 1 \\
\hline
\end{tabular}

LOE, level of evidence.

in stroke volume as a compensatory mechanism against $\mathrm{OI}^{24}$ (table 1).

\section{THE ROLES OF HEAT AND DEHYDRATION}

Although dehydration leading to hyperthermia has been postulated as a primary factor for EAC, ${ }^{5-7}$ there is no evidence to support its overall responsibility for OI or EAC in endurance athletes. ${ }^{25}$ Evidence, however, supports both heat stress and increased skin temperature as contributing factors in OI. Heat stress results in the reduction of baroreflex control in response to an orthostatic challenge. ${ }^{26}$ Heat stress has also been postulated to impair aerobic exercise performance, primarily through increased cardiovascular strain. ${ }^{27}$ In addition, increasing body temperature may increase cerebral vascular resistance, reducing the cerebral threshold for neurogenic collapse. ${ }^{28}$

Two small studies found that laboratory-induced hypovolemia may lead to changes in baroreflex control of blood pressure in certain individuals, which may increase susceptibility to EAC. ${ }^{22}{ }^{29}$ However, a larger clinical trial following the body composition of 31 runners completing an ultramarathon event found that the collapsed runners did not have a higher body temperature than those who did not collapse, and all the runners were dehydrated, but this level of dehydration was unrelated to the degree of postural hypotension after the event ${ }^{30}$ (table 2). Therefore, although heat and dehydration have not been found to be true causes of EAC or OI in endurance running events, they may possibly be risk factors for EAC or contribute by impairing peripheral vasoconstriction leading to the orthostatic state.

\section{BAROREFLEX MODULATION}

Pooling of blood in the lower extremities at the cessation of exercise has been implicated as a mechanism of EAC; if the systemic vascular resistance, which is reduced during exercise, is not triggered by an intact baroreflex to increase after stopping exercise, a lower body negative pressure (LBNP) situation develops and postural hypotension may occur. LBNP is a widely used technique to study the cardiovascular response to this orthostatic stress. Many studies on the effect of LBNP have shown this altered baroreflex to be a primary mechanism of OI after exercise.

Reduction in baroreflex control has been implicated in the diminished orthostatic response after exercise. ${ }^{31}$ A controlled trial of exercising men found that baroreflex control is altered after dynamic exercise. ${ }^{32}$ Furthermore, in a clinical trial of 51 finishers of a mountain marathon, it was found that a diminished orthostatic response of resistance vessels was the likely aetiology in the OI in these runners after exercise. ${ }^{33}$

In a clinical trial of experienced male runners, systolic blood pressure decreases after exercise secondary to a reduction in peripheral vascular resistance leading to a decreased filling volume. ${ }^{34}$ Women, however, may respond differently to exercise than do men. A controlled clinical trial of both women and men showed that the mechanism of OI in women is likely caused by reduced cardiac filling rather than impaired baroreflex ${ }^{35}$ (table 3).

\section{OTHER}

There is strong evidence to support an attenuated baroreflex response as a responsible mechanism of OI and EAC. It has been seen that heat may contribute to this response. However, 
Table 5 Treatment

\begin{tabular}{|c|c|c|c|c|c|c|}
\hline Ref & Author/journal & Year & Study type & Patients & Outcome & LOE \\
\hline 42 & $\begin{array}{l}\text { Journeay et al } \\
\text { Aviat Space Environ Med }\end{array}$ & 2004 & Randomised controlled trial & 6 subjects & $\begin{array}{l}\text { Lower body positive pressure promoted } \\
\text { restoration of haemodynamics }\end{array}$ & 1 \\
\hline 43 & $\begin{array}{l}\text { Anley et al } \\
\text { Br J Sports Med }\end{array}$ & 2010 & Randomised controlled trial & 28 athletes & $\begin{array}{l}\text { EAPH was effectively treated with } \\
\text { Trendelenburg positions and oral hydration }\end{array}$ & 1 \\
\hline 44 & $\begin{array}{l}\text { Davis and Fortney } \\
\text { Int J Sports Med }\end{array}$ & 1997 & Controlled trial & 5 men & $\begin{array}{l}\text { Fluid ingestion is an effective treatment } \\
\text { for orthostatic intolerance }\end{array}$ & 2 \\
\hline 45 & $\begin{array}{l}\text { Durand et al } \\
\text { Am J Physiol Regul Integr } \\
\text { Comp Physiol }\end{array}$ & 2004 & Randomised controlled trial & 8 subjects & $\begin{array}{l}\text { Skin surface cooling is effective in } \\
\text { improving orthostatic tolerance in } \\
\text { otherwise normothermic individuals }\end{array}$ & 1 \\
\hline 46 & $\begin{array}{l}\text { Wilson et al } \\
\text { J Appl Physiol }\end{array}$ & 2002 & Clinical trial & 9 subjects & $\begin{array}{l}\text { Skin surface cooling may protect against } \\
\text { orthostatic intolerance in heat stressed } \\
\text { humans }\end{array}$ & 3 \\
\hline 47 & $\begin{array}{l}\text { Cui et al } \\
\text { Am J Physiol Heart Circ } \\
\text { Physiol }\end{array}$ & 2005 & Controlled trial & 9 subjects & $\begin{array}{l}\text { Skin surface cooling induced an upward } \\
\text { shift in central venous pressure }\end{array}$ & 2 \\
\hline 48 & $\begin{array}{l}\text { Privett et al } \\
\text { Clin J Sport Med }\end{array}$ & 2010 & Controlled trial & 6 subjects & $\begin{array}{l}\text { Runners who are prone to } 0 \mathrm{l} \text { after } \\
\text { exercise may reduce this risk by wearing } \\
\text { compression stockings while running }\end{array}$ & 2 \\
\hline
\end{tabular}

EAPH, exercise-associated postural hypotension; OI, orthostatic intolerance.

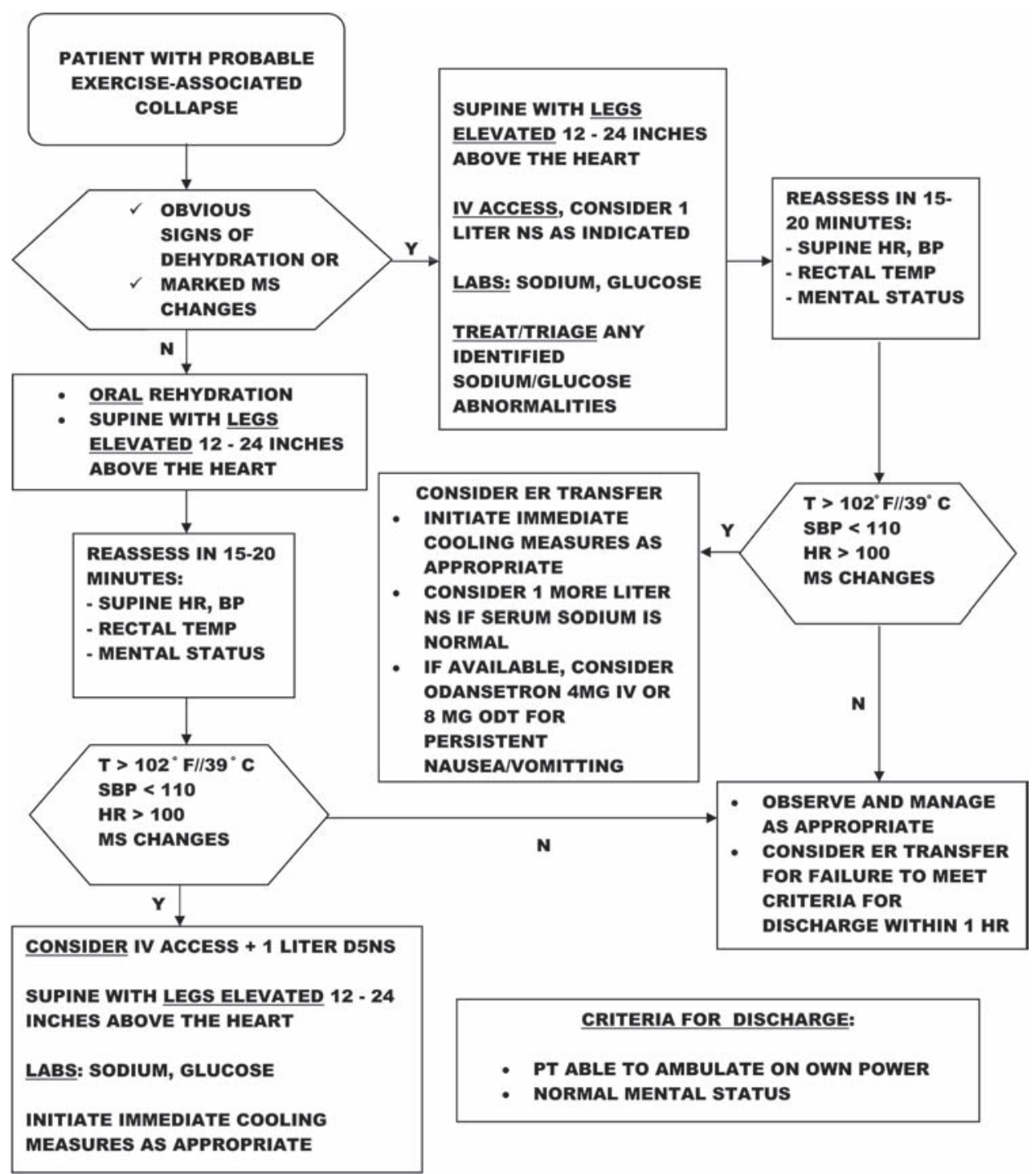

Figure 1 Exertional collapse algorithm. 
there are several other factors that have been studied, which may also exacerbate this response.

Hypoglycaemia has been found to attenuate baroreflex sensitivity, which may be important because serum glucose levels will decrease as length of exercise increases, which may make endurance and ultraendurance athletes more susceptible to EAC. ${ }^{36}$ Pushing the pace or aiming for a time goal has also been implicated in EAC. ${ }^{30}$ As the respiratory rate of athletes increases as they try to attain a cutoff or time goal, their level of carbon dioxide will decrease as a result. Studies have shown that hypercarbia may be protective, ${ }^{37}$ and this resultant hypocapnia may further attenuate the baroreflex response. ${ }^{38}$

Medications may also affect response to LBNP - antidepressant medications have been shown to lead to a significant impairment in cardiovascular reflex response after exercise, which may implicate neurochemicals as possible factors in EAC. ${ }^{39}$ In addition, in two separate randomised controlled clinical trials $\mathrm{H} 1$ and $\mathrm{H} 2$ receptor antagonist medications may blunt the body's postexercise hypotension, suggesting that histamine may also play a role in $\mathrm{EAC}^{4041}$ (table 4).

\section{TREATMENT}

The evidence points towards a lower extremity pooling of blood with an attenuated baroreflex response as the primary mechanism of EAC; therefore, treatment options should be directed primarily at correcting these deficits. Because there is no good evidence to support hyperthermia or dehydration as the primary aetiologies of EAC, total body cooling and intravenous fluids should not have a role in the initial treatment of EAC.

In a randomised controlled trial, it has been shown that lower body positive pressure, such as what occurs in the Trendelenburg positions, promoted restoration of normal haemodynamics. ${ }^{42} 43$ Studies also suggest that oral hydration may be preventive against EAC and may also be used as an effective treatment for EAC. ${ }^{43} 44$ A randomised controlled trial and two smaller trials suggest that skin surface cooling may act towards directing peripheral blood flow centrally and decreasing cardiovascular strain, thus treating EAC. ${ }^{45-47}$ Finally, the results of a study of compression stockings in runners suggest that runners who are prone to OI after exercise may benefit from wearing compression hose while running. ${ }^{48}$ Those prone to EAC may also potentially benefit from taking $\mathrm{H} 1$ or $\mathrm{H} 2$ blocking medications, skin surface cooling along the course and ensuring adequate glucose levels during participation (table 5).

\section{ALGORITHM}

Using the evidence for aetiology, mechanism and treatment, we propose an algorithm, which is currently used at the Marine Corps Marathon, ${ }^{49} 50$ as a clinical framework for the treatment of EAC in endurance athletes (figure 1). The key to using the EAC algorithm is to approach a collapsed athlete with a wide differential that includes potential life-threatening causes such as EAH or EHS and ruling those out with a concise physical examination evaluating mental status and body temperature before proceeding down the EAC algorithm.

\section{CONCLUSION}

EAC is a common occurrence in medical tents after endurance sporting activities, which is typically characterised by collapse after completion of the event in the absence of neurological, biochemical or thermal abnormalities. Although EAC is perhaps the most common aetiology confronted by the medical provider attending to collapsed athletes in a finish-line tent, the provider needs to be reminded that EAC is a diagnosis of exclusion and that he or she needs to be vigilant for other aetiologies that cause collapse. There is no evidence to support the previous idea that EAC is caused primarily by dehydration or heat stroke. These factors, however, along with medications, hypocapnia and hypoglycaemia, may be contributory to EAC. Evidence currently supports that postural hypotension caused by pooling of blood in the lower extremities, secondary to decreased vascular resistance in the face of an attenuated baroreflex response, as the principal mechanism of EAC. Women may sustain EAC more from decreased cardiac filling than from altered baroreflex. Treatment of EAC is usually symptomatic and involves oral hydration and a Trendelenburg position - total body cooling, intravenous hydration or advanced therapies are generally not needed.

Acknowledgements The authors thank Benjamin D Levine, MD for collaboration and suggestions for improving the manuscript.

Competing interests None.

Provenance and peer review Not commissioned; externally peer reviewed.

\section{REFERENCES}

1. Running USA. 2010 Annual Marathon Report. http://www.runningusa.org/ node/76115\#76116 (accessed 27 June 2011).

2. Roberts W0. A 12-yr profile of medical injury and illness for the Twin Cities Marathon. Med Sci Sports Exerc 2000;32:1549-55.

3. Roberts W0. Determining a "do not start" temperature for a marathon on the basis of adverse outcomes. Med Sci Sports Exerc 2010;42:226-32.

4. Holtzhausen LM, Noakes TD. The prevalence and significance of postexercise (postural) hypotension in ultramarathon runners. Med Sci Sports Exerc 1995; 27:1595-601.

5. Cade JR, Free HJ, De Quesada AM, et al. Changes in body fluid composition and volume during vigorous exercise by athletes. J Sports Med Phys Fitness 1971;11:172-8.

6. Rowell LB, Marx HJ, Bruce RA, et al. Reductions in cardiac output, central blood volume, and stroke volume with thermal stress in normal men during exercise. $J$ Clin Invest 1966;45:1801-16.

7. Wyndham $\mathbf{C H}$, Strydom NB. The danger of an inadequate water intake during marathon running. S Afr Med J 1969;43:893-6.

8. Eichna LW, Horvath SM, Bean WB. Post-exertional orthostatic hypotension. Am J Med Sci 1947;213:641-54.

9. Holtzhausen LM, Noakes TD. Collapsed ultraendurance athlete: proposed mechanisms and an approach to management. Clin J Sport Med 1997;7:292-301.

10. OCEBM Levels of Evidence Working Group. "The Oxford 2011 Levels of Evidence". Oxford: Oxford Centre for Evidence-Based Medicine. http://www.cebm.net/ index.aspx?0 $=5653$ (accessed 25 Jun 2011).

11. Roberts W0. Exercise-associated collapse care matrix in the marathon. Sports Med 2007; 37:431-3.

12. Freeman $\mathbf{R}$, Wieling W, Axelrod FB, et al. Consensus statement on the definition of orthostatic hypotension, neurally mediated syncope and the postural tachycardia syndrome. Auton Neurosci 2011;161:46-8.

13. O'Connor FG, Casa DJ, Bergeron MF, et al. American College of Sports Medicine Roundtable on exertional heat stroke-return to duty/return to play: conference proceedings. Curr Sports Med Rep 2010;9:314-21.

14. Armstrong LE, Casa DJ, Millard-Stafford M, et al. American College of Sports Medicine position stand. Exertional heat illness during training and competition. Med Sci Sports Exerc 2007;39:556-72.

15. Noakes TD. A modern classification of the exercise-related heat illnesses. J Sci Med Sport 2008:11:33-9.

16. Morikawa T, Sagawa S, Torii R, et al. Hypovolemic intolerance to lower body negative pressure in female runners. Med Sci Sports Exerc 2001;33:2058-64.

17. Levine BD, Lane LD, Buckey JC, et al. Left ventricular pressure-volume and Frank-Starling relations in endurance athletes. Implications for orthostatic tolerance and exercise performance. Circulation 1991;84:1016-23.

18. Levine BD, Buckey JC, Fritsch JM, et al. Physical fitness and cardiovascular regulation: mechanisms of orthostatic intolerance. J Appl Physiol 1991;70:112-22.

19. Esch BT, Scott JM, Haykowsky MJ, et al. Diastolic ventricular interactions in endurance-trained athletes during orthostatic stress. Am J Physiol Heart Circ Physiol 2007;293:H409-15.

20. Esch BT, Scott JM, Haykowsky MJ, et al. Changes in ventricular twist and untwisting with orthostatic stress: endurance athletes versus normally active individuals. J App/ Physiol 2010;108:1259-66.

21. Convertino VA. Baroreflex-mediated heart rate and vascular resistance responses $24 \mathrm{~h}$ after maximal exercise. Med Sci Sports Exerc 2003;35:970-7. 
22. Ogoh S, Brothers RM, Barnes 0 , et al. Cardiopulmonary baroreflex is reset during dynamic exercise. J Appl Physiol 2006;100:51-9.

23. Ogoh S, Volianitis S, Nissen P, et al. Carotid baroreflex responsiveness to head-up tilt-induced central hypovolaemia: effect of aerobic fitness. J Physiol (Lond) 2003:551:601-8.

24. Convertino VA. Endurance exercise training: conditions of enhanced hemodynamic responses and tolerance to LBNP. Med Sci Sports Exerc 1993;25:705-12.

25. Noakes TD. Exercise in the heat: old ideas, new dogmas. Int Sportmed J 2006;7:58-74.

26. Crandall CG. Heat stress and baroreflex regulation of blood pressure. Med Sci Sports Exerc 2008;40:2063-70.

27. Cheuvront SN, Kenefick RW, Montain SJ, et al. Mechanisms of aerobic performance impairment with heat stress and dehydration. J Appl Physiol 2010;109:1989-95.

28. Wilson TE, Cui J, Zhang R, et al. Heat stress reduces cerebral blood velocity and markedly impairs orthostatic tolerance in humans. Am J Physiol Regul Integr Comp Physio/ 2006;291:R1443-8.

29. Charkoudian N, Halliwill JR, Morgan BJ, et al. Influences of hydration on postexercise cardiovascular control in humans. J Physiol (Lond) 2003;552:635-44.

30. Holtzhausen LM, Noakes TD, Kroning B, et al. Clinical and biochemical characteristics of collapsed ultra-marathon runners. Med Sci Sports Exerc 1994;26:1095-101.

31. Murrell C. Wilson L, Cotter JD, et al. Alterations in autonomic function and cerebral hemodynamics to orthostatic challenge following a mountain marathon. J Appl Physio/ 2007;103:88-96.

32. Halliwill JR, Taylor JA, Eckberg DL. Impaired sympathetic vascular regulation in humans after acute dynamic exercise. J Physiol (Lond) 1996;495 (Pt 1):279-88.

33. Gratze G, Mayer H, Skrabal F. Sympathetic reserve, serum potassium, and orthostatic intolerance after endurance exercise and implications for neurocardiogenic syncope. Eur Heart J 2008;29:1531-41.

34. Privett SE, George KP, Middleton N, et al. The effect of prolonged endurance exercise upon blood pressure regulation during a postexercise orthostatic challenge. Br J Sports Med 2010;44:720-4.

35. Fu 0, Arbab-Zadeh A, Perhonen MA, et al. Hemodynamics of orthostatic intolerance: implications for gender differences. Am J Physiol Heart Circ Physiol 2004;286:H449-57.

36. Adler GK, Bonyhay I, Failing $\mathrm{H}$, et al. Antecedent hypoglycemia impairs autonomic cardiovascular function: implications for rigorous glycemic control. Diabetes 2009:58:360-6.
37. Howden R, Lightfoot JT, Brown SJ, et al. The effects of breathing 5\% CO2 on human cardiovascular responses and tolerance to orthostatic stress. Exp Physiol 2004;89:465-71

38. Lucas SJ, Cotter JD, Murrell C, et al. Mechanisms of orthostatic intolerance following very prolonged exercise. J Appl Physiol 2008;105:213-25.

39. Middleton HC, Maisey DN, Mills IH. Do antidepressants cause postural hypotension by blocking cardiovascular reflexes? Eur J Clin Pharmacol 1987;31:647-53.

40. Lockwood JM, Wilkins BW, Halliwill JR. H1 receptor-mediated vasodilatation contributes to postexercise hypotension. J Physiol (Lond) 2005;563:633-42.

41. McCord JL, Beasley JM, Halliwill JR. H2-receptor-mediated vasodilation contributes to postexercise hypotension. J App/ Physiol 2006;100:67-75

42. Journeay WS, Reardon FD, Jean-Gilles $S$, et al. Lower body positive and negative pressure alter thermal and hemodynamic responses after exercise. Aviat Space Environ Med 2004;75:841-9.

43. Anley C, Noakes T, Collins M, et al. A comparison of two treatment protocols in the management of exercise-associated postural hypotension: a randomised clinical trial. Br J Sports Med 2010; Published Online First: 28 June 2010 doi:10.1136/bjsm.2010.071951.

44. Davis JE, Fortney SM. Effect of fluid ingestion on orthostatic responses following acute exercise. Int J Sports Med 1997;18:174-8.

45. Durand S, Cui J, Williams KD, et al. Skin surface cooling improves orthostatic tolerance in normothermic individuals. Am J Physiol Regul Integr Comp Physiol 2004;286:R199-205

46. Wilson TE, Cui J, Zhang R, et al. Skin cooling maintains cerebral blood flow velocity and orthostatic tolerance during tilting in heated humans. J Appl Physiol 2002;93:85-91.

47. Cui J, Durand S, Levine BD, et al. Effect of skin surface cooling on central venous pressure during orthostatic challenge. Am J Physiol Heart Circ Physiol 2005;289:H2429-33.

48. Privett SE, George KP, Whyte GP, et al. The effectiveness of compression garments and lower limb exercise on post-exercise blood pressure regulation in orthostatically intolerant athletes. Clin J Sport Med 2010;20:362-7.

49. O'Connor, FG, Pyne S, Brennan FA, et al. Exercise-associated collapse: an algorithmic approach to race day management. Am J Medicine and Sports 2003;5:212-17.

50. Brennan FH, O'Connor FG. Emergency triage of collapsed endurance athletes: a stepwise approach to on-site treatment. Phys Sportsmed 2005;33:28-35. 